\title{
Epidemiological profile of women with gynecological cancer in brachytherapy: a cross-sectional study
}

\author{
Perfil epidemiológico de mulheres com câncer ginecológico em braquiterapia: estudo transversal \\ Perfil epidemiológico de las mujeres com cáncer ginecológico em brachiterapia: um estúdio transversal
}

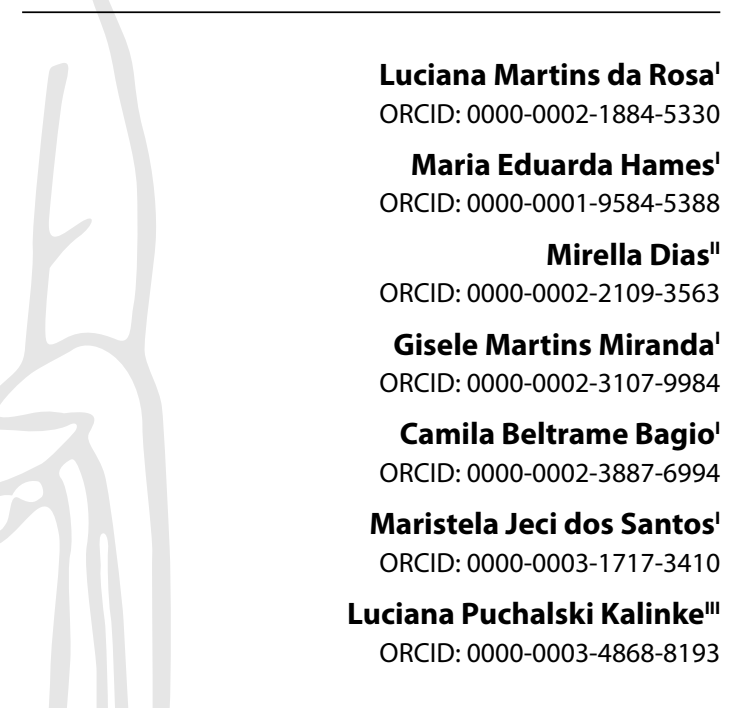

'Universidade Federal de Santa Catarina. Florianópolis, Santa Catarina, Brazil.

"Centro de Pesquisas Oncológicas. Florianópolis, Santa Catarina, Brazil.

I'Universidade Federal do Paraná. Curitiba, Paraná, Brazil.

How to cite this article:

Rosa LM, Hames ME, Dias M, Miranda GM, Bagio CB, Santos MJ, et al. Epidemiological profile of women with gynecological cancer in brachytherapy: a cross-sectional study. Rev Bras Enferm. 2021;74(5):e20200695. https://doi.org/10.1590/0034-7167-2020-0695

Corresponding author:

Luciana Martins da Rosa

E-mail: luciana.m.rosa@ufsc.br

EDITOR IN CHIEF: Dulce Barbosa ASSOCIATE EDITOR: Ana Fátima Fernandes

Approval: $12-06-2020$

\begin{abstract}
Objective: to analyze the sociodemographic and clinical profile of women with gynecological cancer in brachytherapy. Method: a cross-sectional study including records of 1,930 visits of women in brachytherapy assisted between 2006-2016 in Santa Catarina (Brazil). Collection was performed in 2019, in an institutional bank, submitted to frequency measurements, chi-square test, $95 \%$ confidence intervals, significance level of 0.05 . Results: women aged 40-59 years (47.2\%), white (93.3\%); with elementary school (65\%); cervical cancer (78.5\%); stages II-III (73.3\%) figured prominently. In the comparison of staging proportions in the topography variable, a higher proportion of malignant neoplasm of cervix uteri unspecified in the grouped III-IV staging (84.6\%). Conclusion: the profile analysis shows the need for screening and health education for prevention and/or early detection of gynecological cancers and training of nurses specialized in radiotherapy to care for women's health.

Descriptors: Genital Neoplasms, Female; Epidemiology; Nursing; Brachytherapy; Radiotherapy.
\end{abstract}

\section{RESUMO}

Objetivo: analisar o perfil sociodemográfico e clínico de mulheres com câncer ginecológico em braquiterapia. Método: estudo transversal incluindo registros de 1.930 atendimentos de mulheres em braquiterapia assistidas entre 2006-2016 em Santa Catarina (Brasil). Coleta foi realizada em 2019, em banco institucional, submetida às medidas de frequência, Teste Qui-Quadrado, intervalos de $95 \%$ de confiança, nível de significância de 0,05. Resultados: predominaram as mulheres entre $40-59$ anos $(47,2 \%)$, brancas $(93,3 \%)$; com ensino fundamental (65\%); câncer do colo do útero (78,5\%); nos estádios II-III (73,3\%). Na comparação das proporções dos estadiamentos na variável topografia, encontrou-se uma maior proporção da neoplasia maligna do colo do útero não especificada nos estadiamentos III-IV agrupados (84,6\%). Conclusão: a análise do perfil mostra a necessidade do rastreamento e educação em saúde para prevenção e/ou detecção precoce dos cânceres ginecológicos e a formação de enfermeiros especialistas em radioterapia para atendimento da saúde da mulher. Descritores: Câncer Ginecológico; Perfil Epidemiológico; Enfermagem; Braquiterapia; Radioterapia.

\section{RESUMEN}

Objetivo: analizar el perfil sociodemográfico y clínico de mujeres con cáncer ginecológico en braquiterapia. Método: estudio transversal que incluyó registros de 1.930 visitas de mujeres en braquiterapia asistidas entre 2006-2016 en Santa Catarina (Brasil). La recolección se realizóen 2019, en un banco institucional, sometida a medidas de frecuencia, pruebachi-cuadrado, intervalos de confianza al $95 \%$, nivel de significancia de 0,05 . Resultados: predominaron las mujeres entre $40-59$ años $(47,2 \%)$, blancas (93,3\%); con educación primaria (65\%); cáncer de cuello uterino (78,5\%); en estadios II-III (73,3\%). Al comparar las proporciones de estadificación en la variable topografía, encontramos una mayor proporción de malignidad cervical no especificada la estadificación agrupada III-IV (84,6\%). Conclusión: el análisis del perfil muestra la necesidad de cribado y educación sanitaria para la prevención y/o detección temprana de cánceres ginecológicos y la formación de enfermeras especializadas en radioterapia para el cuidado de la salud de la mujer.

Descriptores: Neoplasias de los Genitales Femeninos; Perfil de Salud; Enfermería; Braquiterapia; Radioterapia. 


\section{INTRODUCTION}

Gynecological cancers cover the cervix uteri, corpus uteri, ovary, vulva, vagina, and uterine tubes. Among them, cervical cancer stands out for its worldwide incidence and 569,847 new cases in 2018 (the fourth type of cancer that most affects women) ${ }^{(1)}$.

In Brazil, in 2018, its incidence was approximately 16,298 (crude rate 15.2 ) and mortality affected 8,079 women (crude rate 7.5 ). This epidemiology tends to decrease with the implementation of preventive measures and early detection of non-malignant neoplastic lesions, considering that the disease is linked to repeated infection by the Human Papilloma Virus (HPV), which can be prevented by screening and vaccination programs ${ }^{(1-4)}$.

For the state of Santa Catarina, in 2020, it is estimated that 970 women (gross rate 26.67) may have cervical cancer, 300 women (gross rate 8.22), corpus uteri cancer, and 260 women, (gross rate 7.29) ovarian cancer ${ }^{(5)}$.

In developed countries, the number of cases of cervical cancer has a significant reduction, as in the United States, which has an incidence of 14,065 and a mortality rate of 5,266 . This reduction had a direct influence on the immunization of boys and girls before starting their sex life, because $75 \%$ of people who have an active sex life will be infected with this virus at some point. The vaccine prevents HPV infection 6 and 11 (related to anogenital warts) and 16 and 18 (related to cervical cancer) ${ }^{(1,4)}$.

Treatment varies according to the degree of disease staging, which may include radiotherapy (brachytherapy, teletherapy), chemotherapy, and surgery, which can be combined with each other, providing a better prognosis for patients $s^{(3,6-7)}$. The most widely used intervention when the disease cannot be controlled at the early stage includes the application of external beam radiotherapy in the pelvis (teletherapy) together with chemotherapy. Cisplatin is the preferred medication; sequentially, patients are referred to pelvic brachytherapy ${ }^{(4,8)}$.

Brachytherapy stands out, which consists of an adaptive and image-guided intrauterine radiation therapy. Currently, high dose rate brachytherapy has been the most widely used, considering its advantages when compared to those with low dose rate. The main advantages are the form of radiation administration, three to four radiation applications for about 12 minutes and the smallest side effects $^{(7)}$.

It should also be noted that brachytherapy is considered a safe technique for patients with cervical and endometrial cancer, the most prevalent topographies among gynecological cancers, and with very satisfactory results of regression and even healing of tumors and with lower toxicity to adjacent normal tissues ${ }^{(9)}$.

he Oncological Research Center (CEPON - Centro de Pesquisas Oncológicas), a reference in oncologic care in the state of Santa Catarina (Brazil) and setting of this investigation, was the only institution to offer pelvic brachytherapy of high dose rate between 2006 and 2016 to women with gynecological cancers living in the state. Thus, all women from Santa Catarina who required pelvic brachytherapy were assisted in CEPON in the aforementioned time cut. The availability of data for this time cut only occurred in 2019, after completion of information collection and storage by CEPON's Cancer Hospital Registry (RHC - Registro Hospitalar de Câncer). The sociodemographic profile and clinical profile of these women have not yet been investigated, and this type of study contributes to nursing and health management and planning with a view to promotion, prevention, early detection, timely treatment and palliative care.

\section{OBJECTIVE}

To analyze the sociodemographic and clinical profile of women with gynecological cancer in brachytherapy.

\section{METHODS}

\section{Ethical aspects}

This study followed the legal determinations for human research of the Brazilian National Health Council (Conselho Nacional de Saúde) ${ }^{(10)}$. It was assessed by the Research Ethics Committees with Human Beings of the proponent and co-participant of the study. Considering the universe of research, the exemption from the application of an Informed Consent Form was authorized.

\section{Study design, period, and location}

This is an observational study in cross-sectional, documentary epidemiology, with secondary data from the years 2006-2016, based on the STROBE Statement-checklist of items that should be included in reports of cross-sectional studies ${ }^{(11)}$, with data collection performed between August and December 2019, using CEPON as a setting.

\section{Population, inclusion and exclusion criteria}

Women (1,968 records of care) with gynecological cancer submitted to brachytherapy between December 2006 and December 2016 , with or without other associated therapies, participated in the study. Records of women with gynecological cancer submitted to brachytherapy in the period 2006-2016 were included. Records of topography of the genital tract of sarcomas and oncohematological neoplasms were excluded. After applying these criteria, 1,930 records were obtained as the final sample, analyzed in this study.

\section{Study protocol}

Data collection occurred at two consecutive moments. First, in the Book of Records of Brachytherapys of the Physical-Medical Sector, the number of patients' medical records and the number of brachytherapy sessions prescribed were collected as variables. This collection was necessary because teletherapy and brachytherapy are recorded with the same code (RT) in CEPON's RHC. This type of record prevented the identification of women undergoing brachytherapy, considering that some women with gynecological cancer perform only teletherapy or brachytherapy, and other women require teletherapy followed by brachytherapy. The number of brachytherapy sessions is not recorded in the RHC, so it was collected in the aforementioned record book.

The numbers of medical records after collection were entered in a spreadsheet constructed in the Microsoft Excel program and sent to CEPON's RHC, when the following variables were grouped and investigated: age (first consultation at CEPON and diagnosis); race/skin color; marital status; degree of education; origin; year of first consultation at the institution; treatment and diagnosis prior to the first consultation at CEPON; clinical staging; treatments 
performed at CEPON; topographies of diseases according to the International Classification of Diseases for Oncology (ICD-O): vulva (C51.0; C51.1; C51.2; C51.8; C51.9); vagina (C52.9); cervix uteri (C53.0; C53.1; C53.8; C53.9); corpus uteri (C54.0; C54.1; C54.2; C54.3; C54.8; C54.9); uterus (C55.9);ovary (C56.9).Data were made available to researchers in Excel spreadsheets. Thus, data collection was performed by researchers and $\mathrm{RHC}$ professionals from CEPON.

\section{Analysis of results, and statistics}

The data provided by CEPON's RHC were organized and coded for submission to descriptive and inferential statistical analysis, performed by a statistical professional.

Categorical variables were represented by absolute, relative frequency and their respective $95 \%$ confidence intervals. One or more forms of treatments were indicated to the women included in this study, and this variable was descriptively analyzed by multiple response statistics. The proportions of the variables studied were compared between the staging by the Chi-Square Test. The stagingwere reclassified into three groups: grouped in situ, I and II and III and IV grouped. When significant, the local analysis was verified by the analysis of standardized adjusted residues, emphasizing the categories with values greater than or equal to 1.96. The significance level established was $5 \%$. The analyses were completed using SPSS software, version 18. The discussion of results was supported by scientific publications related to the research theme.

\section{RESULTS}

The highest predominance was found among women with white skin color, 1,801 (93.3\%); with elementary education (incomplete/ complete), 1,255 (65\%); with a partner, 1,053 (54.5\%) (Table 1).

The highest percentage of women's ages was found in the $50-59$ age group, 469 (24.3\%), followed by the $40-49$ years age group, 442 (22.9\%); among those who received four bratherapy sessions, 1,304 (67.6\%) and with diagnosis and treatment prior to the first consultation at CEPON, 1,492 (77.3\%). Concerning staging classification, the proportions were very similar and close to $36 \%$ in stages II and III, 1,328 (73.3\%) (Table 2).

In the comparison of the staging proportions between the variables studied, no effect was found on the variables age in the first consultation, level of education or origin ( $p>=0.05$ ), i.e., fixing a category of a variable, the proportions were not different between the staging. In the topography variable, there was a difference in the staging proportions; a higher proportion of malignant neoplasm of the cervix uteri was unspecified in the grouped staging III and IV (84.6\%) and a higher proportion of malignancy of the endometrium with grade I and II grouped (24.2\%) when compared to the proportion of the other categories of staging. Other higher proportions, compared with staging, identified in the chi-square test, were age at diagnosis of 60-69 years (20.6\%) and malignant neoplasm of the vagina in the in situstage (46.7\%). Table 3 presents all the findings (data without information were not included in the calculations).

A higher predominance was also found among women from Greater Florianópolis, 628 (34.1\%) and diagnosed with malignant neoplasms affecting cervix uteri (C53.0, C53.8, C53.9), 1,421 (78.5\%) (Table 3).
Table 1 - Race, level of education and marital status of the study population, Florianópolis, Santa Catarina, Brazil, $2020(\mathrm{~N}=1,930)$

\begin{tabular}{|c|c|c|}
\hline & $\mathbf{n}$ & $\%[95 \% \mathrm{Cl}]^{*}$ \\
\hline \multicolumn{3}{|l|}{ Race/skin color } \\
\hline White & 1801 & $93.3[92.1 ; 94.4]$ \\
\hline Black & 43 & $2.2[1.6 ; 3]$ \\
\hline Yellow & 2 & $0.1[0 ; 0.3]$ \\
\hline Mixed ethnicity & 77 & $4[3.2 ; 4.9]$ \\
\hline No information & 7 & $0.4[0.2 ; 0.7]$ \\
\hline \multicolumn{3}{|l|}{ Degree of education } \\
\hline None & 79 & $4.1[3.3 ; 5]$ \\
\hline Incomplete elementary school & 504 & $26.1[24.2 ; 28.1]$ \\
\hline Complete elementary school & 751 & $38.9[36.8 ; 41.1]$ \\
\hline High school & 306 & $15.9[14.3 ; 17.5]$ \\
\hline Incomplete higher education & 25 & $1.3[0.9 ; 1.9]$ \\
\hline Complete higher education & 108 & $5.6[4.6 ; 6.7]$ \\
\hline No information & 157 & $8.1[7 ; 9.4]$ \\
\hline \multicolumn{3}{|l|}{ Marital status } \\
\hline Single & 315 & $16.3[14.7 ; 18]$ \\
\hline Married & 952 & $49.3[47.1 ; 51.6]$ \\
\hline Widowed & 273 & $14.1[12.6 ; 15.8]$ \\
\hline Legally separated & 210 & $10.9[9.6 ; 12.3]$ \\
\hline Consensual union & 101 & $5.2[4.3 ; 6.3]$ \\
\hline No information & 79 & $4.1[3.3 ; 5]$ \\
\hline
\end{tabular}

Source: Oncological Research Center's Cancer Hospital Registry (Santa Catarina/Brazil). Note: *Descriptive analysis; $\mathrm{Cl}$ - $95 \%$ confidence interval.

Table 2 - Age at the first consultation, previous diagnosis and treatment, staging of the disease and number of brachytherapy sessions of the study population, Florianópolis, Santa Catarina, Brazil, $2020(\mathrm{~N}=1,930)$

\begin{tabular}{|c|c|c|}
\hline & $\mathbf{n}$ & $\%[95 \% \mathrm{Cl}]^{*}$ \\
\hline \multicolumn{3}{|l|}{ Age at first consultation } \\
\hline $18 \mid--20$ & 1 & $0.1[0 ; 0.2]$ \\
\hline $20 \mid--30$ & 80 & $4.1[3.3 ; 5.1]$ \\
\hline $30 \mid--40$ & 346 & $17.9[16.3 ; 19.7]$ \\
\hline $40 \mid--50$ & 442 & $22.9[21.1 ; 24.8]$ \\
\hline $50 \mid--60$ & 469 & $24.3[22.4 ; 26.3]$ \\
\hline $60 \mid--70$ & 364 & $18.9[17.2 ; 20.7]$ \\
\hline $70|--| 95$ & 227 & $11.8[10.4 ; 13.3]$ \\
\hline No information & 1 & $0.1[0 ; 0.2]$ \\
\hline \multicolumn{3}{|l|}{ Previous diagnosis and treatment } \\
\hline No diagnostics/no treatment & 22 & $1.1[0.7 ; 1.7]$ \\
\hline With diagnostics/without treatment & 413 & $21.4[19.6 ; 23.3]$ \\
\hline With diagnosis/with treatment & 1492 & $77.3[75.4 ; 79.1]$ \\
\hline Others & 1 & $0.1[0 ; 0.2]$ \\
\hline No information & 2 & $0.1[0 ; 0.3]$ \\
\hline \multicolumn{3}{|l|}{ Staging } \\
\hline In situ & 15 & $0.8[0.5 ; 1.3]$ \\
\hline 1 & 377 & $20.8[19 ; 22.7]$ \\
\hline II & 648 & $35.8[33.6 ; 38]$ \\
\hline III & 680 & $37.5[35.3 ; 39.8]$ \\
\hline IV & 92 & $5.1[4.1 ; 6.2]$ \\
\hline No information & 118 & $6.1[5.1 ; 7.2]$ \\
\hline \multicolumn{3}{|l|}{ Brachytherapy prescribed } \\
\hline 2 sessions & 90 & $4.7[3.8 ; 5.7]$ \\
\hline 3 sessions & 500 & $25.9[24 ; 27.9]$ \\
\hline 4 sessions & 1304 & $67.6[65.5 ; 69.6]$ \\
\hline 5 sessions & 35 & $1.8[1.3 ; 2.5]$ \\
\hline 6 sessions & 1 & $0.1[0 ; 0.2]$ \\
\hline
\end{tabular}

Source: Oncological Research Center's Cancer Hospital Registry (Santa Catarina/Brazil). Note: *Descriptive analysis; Cl-95\% confidence interval.

Applying the multiple response analysis, it was identified that 2,870 types of treatments were prescribed from the first consultation at CEPON. Radiotherapy (brachytherapy associated or not with teletherapy) was found in 2,309 records (80.5\%), followed by chemotherapy, with 503 records (17.5\%) (Table 4). 
Table 3 - Comparison of the proportions of disease staging among the variables studied, Florianópolis, Santa Catarina, Brazil, 2020

\begin{tabular}{|c|c|c|c|c|c|c|}
\hline & $\mathbf{n}$ & $\begin{array}{l}\text { Total } \\
\text { \% [95\%Cl]* }\end{array}$ & $\begin{array}{c}\text { in situ } \\
\text { n (\%) }\end{array}$ & $\begin{array}{l}\text { Staging** } \\
\text { I+II } \\
\text { n (\%) }\end{array}$ & $\begin{array}{l}\text { III+IV } \\
\text { n (\%) }\end{array}$ & $p$ \\
\hline Age at diagnosis $(\mathrm{N}=1,807)$ & & & & & & 0.040 \\
\hline $\min \mid--20$ & 2 & $0.1[0 ; 0.4]$ & $0(0)$ & $1(0.1)$ & $1(0.1)$ & \\
\hline $20 \mid-30$ & 86 & $4.8[3.8 ; 5.8]$ & $0(0)$ & $42(4.1)$ & $44(5.7)$ & \\
\hline $30 \mid--40$ & 340 & $18.8[17.1 ; 20.7]$ & $4(26.7)$ & 192(18.8) & 144(18.7) & \\
\hline $40 \mid--50$ & 414 & $22.9[21 ; 24.9]$ & $2(13.3)$ & $221(21.6)$ & $191(24.8)$ & \\
\hline $50 \mid--60$ & 444 & $24.6[22.6 ; 26.6]$ & $1(6.7)$ & $258(25.3)$ & 185(24) & \\
\hline $60 \mid--70$ & 334 & $18.5[16.7 ; 20.3]$ & $5(33.3)$ & $210(20.6)$ & $119(15.4)$ & \\
\hline $70|--|$ Max & 187 & $10.3[9 ; 11.8]$ & $3(20)$ & $97(9.5)$ & $87(11.3)$ & \\
\hline Education level $(\mathrm{N}=1661)$ & & & & & & 0.542 \\
\hline None & 75 & $4.5[3.6 ; 5.6]$ & $1(7.7)$ & 34(3.6) & $40(5.6)$ & \\
\hline Incomplete elementary school & 486 & $29.3[27.1 ; 31.5]$ & $5(38.5)$ & $266(28.4)$ & $215(30.3)$ & \\
\hline Complete elementary school & 689 & $41.5[39.1 ; 43.9]$ & $5(38.5)$ & 393(41.9) & 291(41) & \\
\hline High school & 286 & $17.2[15.5 ; 19.1]$ & $2(15.4)$ & $170(18.1)$ & 114(16.1) & \\
\hline Incomplete higher education & 25 & $1.5[1 ; 2.2]$ & $0(0)$ & 18(1.9) & $7(1)$ & \\
\hline Complete higher education & 100 & $6[5 ; 7.2]$ & $0(0)$ & $57(6.1)$ & $43(6.1)$ & \\
\hline Origin $(\mathrm{N}=1,812)$ & & & & & & 0.343 \\
\hline Greater Florianópolis & 628 & $34.7[32.5 ; 36.9]$ & $4(26.7)$ & $364(35.5)$ & $260(33.7)$ & \\
\hline Northeast & 203 & $11.2[9.8 ; 12.7]$ & $4(26.7)$ & $117(11.4)$ & $82(10.6)$ & \\
\hline Vale do Itajaí & 32 & $1.8[1.2 ; 2.5]$ & $0(0)$ & 16(1.6) & $16(2.1)$ & \\
\hline North Plateau & 60 & $3.3[2.6 ; 4.2]$ & $0(0)$ & $32(3.1)$ & $28(3.6)$ & \\
\hline Itajaí River Mouth & 7 & $0.4[0.2 ; 0.8]$ & $0(0)$ & $2(0.2)$ & $5(0.6)$ & \\
\hline South & 289 & $15.9[14.3 ; 17.7]$ & $6(40)$ & $158(15.4)$ & $125(16.2)$ & \\
\hline Far West & 268 & $14.8[13.2 ; 16.5]$ & $0(0)$ & $152(14.8)$ & $116(15)$ & \\
\hline Midwest & 222 & $12.3[10.8 ; 13.8]$ & 1(6.7) & $120(11.7)$ & 101(13.1) & \\
\hline Plateau & 103 & $5.7[4.7 ; 6.8]$ & $0(0)$ & $64(6.2)$ & $39(5.1)$ & \\
\hline Topography ICD-10*** (N=1812) & & & & & & $<0.001$ \\
\hline C51.9 & 1 & $0.1[0 ; 0.3]$ & $0(0)$ & $0(0)$ & $1(0.1)$ & \\
\hline C52.9 & 24 & $1.3[0.9 ; 1.9]$ & $7(46.7)$ & $11(1.1)$ & $6(0.8)$ & \\
\hline C53.0 & 16 & $0.9[0.5 ; 1.4]$ & $0(0)$ & $8(0.8)$ & $8(1)$ & \\
\hline C53.8 & 1 & $0.1[0 ; 0.3]$ & $0(0)$ & $1(0.1)$ & $0(0)$ & \\
\hline C53.9 & 1404 & $77.5[75.5 ; 79.4]$ & $8(53.3)$ & $743(72.5)$ & $653(84.6)$ & \\
\hline C54.1 & 342 & $18.9[17.1 ; 20.7]$ & $0(0)$ & $248(24.2)$ & $94(12.2)$ & \\
\hline C54.2 & 1 & $0.1[0 ; 0.3]$ & $0(0)$ & $1(0.1)$ & $0(0)$ & \\
\hline C54.3 & 1 & $0.1[0 ; 0.3]$ & $0(0)$ & $1(0.1)$ & $0(0)$ & \\
\hline C54.8 & 1 & $0.1[0 ; 0.3]$ & $0(0)$ & $0(0)$ & $1(0.1)$ & \\
\hline C54.9 & 18 & $1[0.6 ; 1.5]$ & $0(0)$ & $11(1.1)$ & $7(0.9)$ & \\
\hline C55.9 & 2 & $0.1[0 ; 0.4]$ & $0(0)$ & $1(0.1)$ & $1(0.1)$ & \\
\hline C56.9 & 1 & $0.1[0 ; 0.3]$ & $0(0)$ & $0(0)$ & $1(0.1)$ & \\
\hline
\end{tabular}

Source: Oncological Research Center's Cancer Hospital Registry (Santa Catarina/Brazil).

Note: *Descriptive analysis; **Chi-square test. In particular, the cases with standardized adjusted residue analysis greater than 1.96; C51.9-Malignant neoplasm of vulva, unspecified; C52.9-Malignant neoplasm of vagina; C53.0 - Malignant neoplasm of endocervix; C53.8 - Malignant neoplasm of overlappingsites of cervix uteri; C53.9-Malignant neoplasm of cervix uteri, unspecified; C54.1 - Malignant neoplasm of endometrium; C54.2 - Malignant neoplasm of myometrium; C54.3 - Malignant neoplasm of bottom of the uterus; C54.8 - Malignant neoplasm of overlapping lesion ofcorpus uteri; C54.9 - Malignant neoplasm of corpus uteri,unspecified; C55.9-Malignant neoplasm of uterus, part unspecified; C56.9 - Malignant neoplasm of unspecified ovary.

Among the therapies performed at CEPON, brachytherapy alone was the most prevalent. 1,337 women (69.3\%) were submitted to therapy. The association of teletherapy with chemotherapy, followed by brachytherapy, was the second most prevalent, being indicated to 294 women (15.2\%); 176 women (9.1\%) underwent surgery and brachytherapy; other therapeutic associations ranged from 1 to 59 indications.

Table 4 - Treatments performed by the study population according to multiple response analysis,. Florianópolis, Santa Catarina, Brazil, 2020, (N=1,930)

\begin{tabular}{lcc}
\hline Treatment types & $\mathbf{n}$ & $\%[\mathbf{9 5 \% C l}]$ \\
\hline Surgery & 55 & $1.9[1.5 ; 2.5]$ \\
Radiotherapy (brachytherapy and/or teletherapy) & 2309 & $80.5[79.0 ; 81.9]$ \\
Chemotherapy & 503 & $17.5[16.2 ; 18.9]$ \\
Hormone therapy & 3 & $0.104[0.03 ; 0.28]$ \\
Total & 2870 & 100 \\
\hline
\end{tabular}

Source: Oncological Research Center's Cancer Hospital Registry (Santa Catarina/Brazil).
Most of women came from Greater Florianópolis (22 municipalities near Florianópolis), 628 (34.7\%); however, the sum of the other origins was equivalent to $1,184(65.3 \%)$, which shows that the majority of women treated at CEPON underwent treatment outside the home.

The year 2014 corresponded to the year with the highest number of first-time consultations performed by CEPON to women with gynecological cancer in brachytherapy, when 248 women (12.8\%) were assisted (Figure 1).

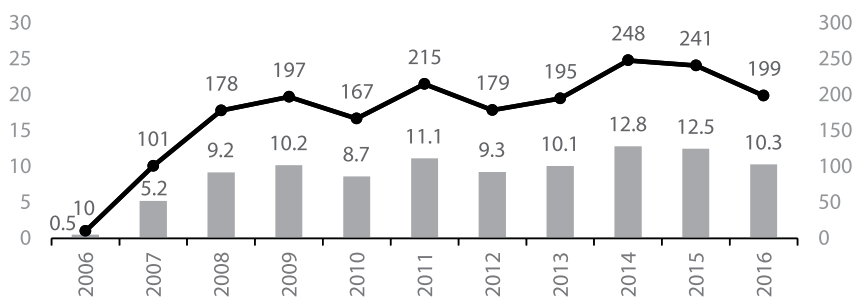

Figure 1 - Frequency of the first consultation of women in pelvic brachytherapy at the Oncological Research Centerbetween 2006-2016. Florianópolis, Santa Catarina, Brazil, 2020 ( $N=1,930)$ 


\section{DISCUSSION}

The higher incidence of gynecological cancer cases occurring in cervical topography reaffirms the worldwide epidemiology that points to this type of cancer as the most incident ${ }^{(12)}$. However, it should be noted that endometrial cancer is the most common gynecological neoplasm in developed countries, with an increasing incidence, differing from cervical cancer that is most commonin countries with lower income ${ }^{(2)}$. Thus, this study shows that the prevention of cervical cancer in Santa Catarina still needs greater attention from the health system.

The International Agency for Research on Cancer states that in 2018 there were about 570,000 new cases of cervical cancer, with a cumulative incidence $(1 / 100)$ of $1.36 \%$. The highest cumulative incidences among gynecological cancers were found in East Africa, with 52,633 new cases of cervical cancer (4.34\%); in North America, with 380,000 new cases of corpus uteri cancer (2.55\%); in Eastern and Central Europe, with 295,000 new cases of ovarian cancer (1.31\%); in East Africa, with 44,000 new cases of vulva cancer (0.56); in the Caribbean, with 17,000 new cases of vagina cancer $(0.15 \%)^{(12)}$.

The age for diseases' diagnoses was close to the findings of other studies. A review study indicates that women with endometrial cancer are diagnosed at 60 years (mean age) with ovarian cancer between 55-65 years, in vagina, $>60$ years and in vulva, between $75-84$ years $^{(13)}$. An American study shows that $54 \%$ of women with cervical cancer are diagnosed under 50 years of age, followed by women aged 50-69 years (33\%) and with localized diseases $^{(14)}$. In an ecological study of time series conducted in Brazil, it was observed that the risk of death from cervical cancer increases in women from 60 years of age $\mathrm{e}^{(15)}$.

In view of these findings and those found by this study, the importance of attention to women in all age groups for prevention and/or early detection of gynecological cancers is evidenced. The chance of illness with worse staging and prognoses prevails in older women; however, high numbers have been identified since the age of 30 , which portrays the relevance of early detection from the age group before 30 years to 70 years.

The skin color of women in this study was predominantly white, differing from other studies that indicate a higher number among women of black or non-white color ${ }^{(16-17)}$. An American study points out that black women have higher incidence and mortality rates and lower survival than white women. A Brazilian study indicates that non-white women are equivalent to $91.75 \%{ }^{(16)}$. With regard to the difference found, colonization in Santa Catarina is strongly related to European countries. More than 5 million Santa Catarina are white, followed by 800,000 browns and 183,000 blacks, 26,000 yellows and about 16,000 indigenous ${ }^{(18)}$. Therefore, the findings of this study could not be similar to that of other studies, because the number of black women in the state is lower than the populations of other studies.

A study points out that cities where most are black (black and brown) have the worst living conditions and health, the worst rates of human development and the lowest life expectancy of their residents ${ }^{(19)}$; this condition favors the development of cervical cancer, the most common topography among all types of gynecological cancers. Thus, it can be said that the life condition overlaps with the aspect of race as a risk factor for the disease.
Regarding the level of education, another similarity occurred, because a study indicates that $55.6 \%$ of women with cervical cancer have up to seven years of education, than women with low level of education ( $\mathrm{OR}=4.07 ; \mathrm{Cl} 95 \%=2.06-8.16)$ and race/ non-white color $(\mathrm{OR}=2.22 ; \mathrm{Cl} 95 \%=1.05-4.65)$ is associated with the involvement of high-grade lesions ${ }^{(20)}$. In another study, the percentage of education up to elementary school (incomplete/ complete) was equal to $61.37 \%{ }^{(16)}$. Marital status in this study and in others showed no significant difference, since about half or more of the cases occur in married women/consensual union ${ }^{(17,20-21)}$.

The staging found had a predominance of stages II and III, a similar result found in another Brazilian study, which pointed out that $39.5 \%$ of women on radiotherapy were diagnosed on stage II and $45.9 \%$ in stage III $^{(22)}$. However, it is worth noting that cases of cervical cancer, most cases in this investigation, in the comparison of proportions with staging, prevailed the higher stages. Considering the context investigated, which includes only women in brachytherapy, indicated in cases of more advanced diseases, such a fact can be justified. However, it is evident the slowness of the health system to start treatment in high stage complexity that may allow better prognoses and lower complications.

From this perspective, the importance of implementing the Brazilian guidelines ${ }^{(23)}$ is reinforced, covering actions in primary care and medium complexity for cervical cancer screening, with early identification and treatment of neoplastic lesions and early detection and treatment of malignant neoplastic lesions. Similar care should also be adopted for other types of gynecological cancers, considering the absence of specific policies.

Regarding the comparison of proportions between endometrium topography and staging, which showed stages I and II as the most frequent, this finding is also similar to the findings of korean study (stage I 34.9\%; II 27.9\%), which still indicates that $52.3 \%$ of women were treated only with surgery, $18.6 \%$ with surgery and radiotherapy and $2.3 \%$ with surgery, chemotherapy and radiotherapy ${ }^{(24)}$.

Regarding the therapeutic modalities found in the Korean study, it is not possible to make any changes with that presented in this study, because the results in Korea cover all cases of the disease and the therapeutic modalities indicated ${ }^{(24)}$. In this study, the investigation was limited to women who required brachytherapy. Thus, women who required other therapeutic modalities to control the disease and did not need to perform treatment outside the home were not treated in the study setting. Moreover, $\mathrm{RHC}$ records only identify women who underwent treatments prior to the first consultation at CEPON, but do not record what type of treatment was performed.

The three main gynecological cancers are that of cervix uteri, endometrium and ovary. Cervical cancer is the fourth most common malignancy in women worldwide, resulting in more than 300,000 deaths in $2018^{(2)}$. Ovarian cancer caused 184,799 deaths in the same year ${ }^{(1)}$, while corpus uteri cancer almost 90,000 deaths in 2018, and endometrial carcinomas represent the largest number of these cases, because less than $10 \%$ of corpusuteri cancers are sarcomas. Endometrioid carcinomas make up more than $83 \%$ of corpus uteri cancers ${ }^{(1.24)}$. This epidemiological condition alone reveals the urgency of attention to women in the prevention and early detection of gynecological cancers. 


\section{Study limitations}

As a limitation of this study, the incompleteness of some data is considered. The staging of cases is exemplified, since 118 women were without this record and the absence of records of therapeutic forms performed before the first consultation in CEPON according to the standards adopted by the CEPON RHC. In this study, we decided to maintain the inclusion of cases with the incompleteness of the information to evidence this reality, despite the limit imposed on statistical calculations.

\section{Contributions to nursing, health, and public policies}

The implications for nursing considering the profile revealed here cover the relevance of health education practices, while the lowest education rates remain in the national territory; the priority periodic health assessment of women between 25 and 70 years of age, in order to ensure the prevention and early detection of gynecological cancers, especially cervical cancer; the demystification of the HPV vaccine, considering its protective factor for girls/women. It is worth highlighting the importance of specialized training of nurses to work in the context of radiotherapy/ brachytherapy, because the reduced number of these professionals is still found in the various institutional settings. Thus, it is considered that the results pointed out by the study can contribute to better management in health and nursing care in CEPON and Primary Health Care in the state of Santa Catarina.

\section{CONCLUSION}

The sociodemographic profile of women from Santa Catarina in brachytherapy between 2006-2016 shows the age between 40-59 years, with white skin color, with lower degrees of education, with partners and coming from Greater Florianópolis as the group most affected by gynecological cancers. As for clinical profile, women with malignant neoplasms affecting the cervix uteri in staging II and III predominate In the comparison of stagingproportions between the variables studied, no effect was found on the variables age in the first consultation and education or origin degree $(p>=0.05)$. In the ICD-O topography variable, there was a difference $(p<0.001)$, a higher proportion of malignant neoplasm of cervix uteriunspecified in the grouped staging III and IV and of malignant neoplasm of endometrium with grade I and II grouped.

\section{REFERENCES}

1. Bray F, Ferlay J, Soerjomataram I, Siegel RL, Torre LA, Jemal A. Global cancer statistics 2018: GLOBOCAN estimates of incidence and mortality worldwide for 36 cancers in 185 countries. CA Cancer J Clin. 2018;68(6):394-24. https://doi.org/10.3322/caac.21492

2. Lee SY, Kim E, Kim HS, Koo YJ, Lee DH. Clinical and histopathologic analysis of gynecological cancer: a single institute experience over 7 years. Yeungnam Univ J Med. 2020;yujm.2019.00451. https://doi.org/10.12701/yujm.2019.00451

3. Cheung T, Lau Joseph JTF, Wang JZ, Mo P, Siu CK, Chan RTH, Ho JYS. The acceptability of HPV vaccines and perceptions of vaccination against HPV among physicians and nurses in Hong Kong. Int J Environ Res Public Health. 2019; 16(10):e1700. https://doi.org/10.3390/ijerph16101700

4. Bakker RM, Mens JWM, Groot HE, Tuijnman-Raasveld CC, Braat C, Hompus WCP et al. A nurse-led sexual rehabilitation intervention after radiotherapy for gynecological cancer. Support Care Cancer. 2017;25:729-37. https://doi.org/10.1007/s00520-016-3453-2

5. Instituto Nacional de Câncer José Alencar Gomes da Silva (BR). Estimativa 2020: incidência de câncer no Brasil. Rio de Janeiro: INCA; 2019.

6. Valakh V, Coopey BC. Factors Associated with duration of overall treatment time for cervical cancer treated with definitive chemoradiotherapy. Cureus. 2019;11(10):e5951. https://doi.org/10.7759/cureus.5951

7. Nurkic SR, Ocampo Al, Gadea MJP, Greenwalt J, Vicente MJ, Velasquez AL, et al. Implementation of high dose-rate brachytherapy for cervix cancer in a low-income country. Ann Glob Health. 2018;84(4):679-82. https://doi.org/10.29024/aogh.2377

8. Zhang Daguang, Yang Zhiyong, Jiang Shan, Zhou Lin, Zhou Zeyang, Wang Wei. Individualized and inverse optimized needle configuration for combined intracavitary-interstitial brachytherapy in locally advanced cervical cancer. J Can Res Ther. 2019;15:1589-96 https://doi. org/10.4103/jcrt.JCRT_292_19

9. Uyeda M, Friedrich F, Pellizzon ACA. High dose rate (HDR) brachytherapy in gynecologic cancer regression: a review of the literature. Appl Cancer Res. 2018;38(19). https://doi.org/10.1186/s41241-018-0070-z

10. Ministério da Saúde (BR). Conselho Nacional de Saúde. Resolução no 466, de 12 de dezembro de 2012. Aprova diretrizes e normas regulamentadoras de pesquisas envolvendo seres humanos [Internet]. Brasília, Diário Oficial da União, 2012 Dec 12. Brasília; 2012 [cited 2020 May 12]. Available from: http://www.conselho.saude.gov.br/resolucoes/2012/Reso466.pdf

11. Equator Network. STROBE Statement-Checklist of items that should be included in reports of cross-sectional studies [Internet]. United Kingdom: Centre for Statistics in Medicine (CSM), NDORMS, University of Oxford [cited 2020 May 12]. Available from: https://www.equatornetwork.org/wp-content/uploads/2015/10/STROBE_checklist_v4_case-control.pdf

12. Ferlay J, Ervik M, Lam F, Colombet M, Mery L, Piñeros M, et al. Global Cancer Observatory: Cancer Today [Internet]. Lyon, France: International Agency for Research on Cancer; 2018 [cited 2020 May 19]. Available from: https://gco.iarc.fr/today

13. Guirguis-Blake JM, Henderson JT, Perdue LA, Whitlock EP. Screening for Gynecologic Conditions With Pelvic Examination: A Systematic review for the U.S. preventive services task force [Internet]. Rockville (MD): Agency for Healthcare Research and Quality (US); 2017 [cited 2020 May 12]. Available from: https://www.ncbi.nlm.nih.gov/books/NBK442155/table/ch1.t1/ 
14. Quinn BA, Deng X, Colton A, Bandyopadhyay D, Carter JS, Fields EC. Increasing age predicts poor cervical cancer prognosis with subsequent effect on treatment and overall survival. Brachytherapy. 2019;18(1):29-37. https://doi.org/10.1016/j.brachy.2018.08.016

15. Nascimento SG, Carvalho CPAL, Silva RS, Oliveira CM, Bonfim CV. Decline of mortality from cervical cancer. Rev Bras Enferm. 2018;71(Suppl-1):585-90. https://doi.org/10.1590/0034-7167-2016-0530

16. Benard VB, Watson M, Saraiya M, Harewood R, Townsend JS, Stroup AM, et al. Cervical cancer survival in the United States by race and stage (2001-2009): findings from the CONCORD-2 study. Cancer. 2017;123(24):5119-37. https://doi.org/10.1002/cncr.30906

17. Silva RCG, Silva ACO, Peres AL, Oliveira SR. Perfil de mulheres com câncer de colo do útero atendidas para tratamento em centro de oncologia. Rev Bras Saúde Matern Infant. 2018;18(4):695-702. https://doi.org/10.1590/1806-93042018000400002

18. Instituto Brasileiro de Geografia e Estatística (IBGE). Censo 2010 [Internet]. Rio de Janeiro: IBGE; 2010 [cited 2020 May 19]. Available from: https://censo2010.ibge.gov.br/

19. Oliveira BLCA, Luiz RR. Racial density and the socioeconomic, demographic and health context in Brazilian cities in 2000 and 2010 . Rev Bras Epidemiol. 2019;22:e190036. https://doi.org/10.1590/1980-549720190036

20. Melo WA, Pelloso SM, Alvarenga A, Carvalho MDB. Factors associated with abnormalities of the cytopathological uterine cervix test in South of Brazil. Rev Bras Saude Matern Infant. 2017;17(4):637-43. https://doi.org/10.1590/1806-93042017000400002

21. Silva AAL, Rosa LM, Schoeller SD, Radünz V, Martins MM, Martins HIV, et al. Perfil sociodemográfico e clínico de mulheres com câncer no trato genital submetidas à radioterapia. Cogitare Enferm. 2019;24. https://doi.org/10.5380/ce.v24i0.58467

22. Nascimento MI, Silva, GA. Waiting time for radiotherapy in women with cervical cancer. Rev Saúde Pública. 2015;49:92. https://doi. org/10.1590/S0034-8910.2015049005953

23. Instituto Nacional de Câncer José Alencar Gomes da Silva (BR). Coordenação de Prevenção e Vigilância. Divisão de Detecção Precoce e Apoio à Organização de Rede. Diretrizes brasileiras para o rastreamento do câncer do colo do útero 2. ed. rev. atual. Rio de Janeiro: INCA; 2016.

24. Casey MJ, Summers GK, Crotzer D. Cancer, Endometrial [Internet]. Treasure Island (FL): Stat Pearls Publishing; 2020 Jan [cited 2020 May 19]. Available from: https://www.ncbi.nlm.nih.gov/books/NBK525981/ 